\title{
Neuroendocrine Merkel Cell Carcinoma Is Associated with Mutations in Key DNA Repair, Epigenetic and Apoptosis Pathways: A Case-Based Study Using Targeted Massively Parallel Sequencing
}

\author{
Christian A. Graves ${ }^{a, b} \quad$ Ashley Jones $^{b, c}$ Justin Reynolds ${ }^{b}$ Jeremy Stuart ${ }^{d}$ \\ Lucia Pirisi $^{a}$ Peter Botrous ${ }^{b}$ James Wells ${ }^{a, b}$

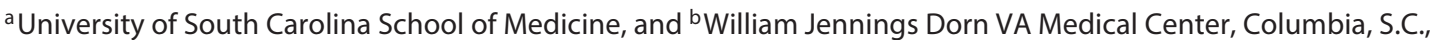 \\ 'Lake Erie College of Osteopathic Medicine, Bradenton, Fla., and d Selah Genomics, Greenville, S.C., USA
}

\section{Key Words}

Merkel cell carcinoma · Neuroendocrine neoplasm .

Merkel cell polyomavirus - Massively parallel sequencing

\begin{abstract}
Introduction: Merkel cell carcinoma (MCC) is a rare neuroendocrine carcinoma with a poorly understood molecular etiology. We implemented a comprehensive deep sequencing approach to identify mutations in the tumor DNA from a cohort of patients treated at our institution over the past 15 years. Our results indicate mutations that may constitute therapeutic targets in MCC. Methods: Five patients were treated for MCC within the study interval. Patients with adequate tissue $(n=4)$, positive neuroendocrine differentiation (chromogranin, synaptophysin, and cytokeratin 20), and histopathological confirmation of MCC were included in the study. DNA was extracted from archival tumor tissue samples and analyzed by massively parallel sequencing using a targeted, multiplex PCR approach followed by semiconductor sequencing. Results: We demonstrate high-penetrance nonsense mutations in PDE4DIP $(n=4)$ as well as various missense mutations in the DNA damage response (PRKDC, AURKB, ERCC5, ATR, and ATRX) and epigenetic
\end{abstract}

modulating enzymes (MLL3). Conclusion: We describe several mutations in potential disease-relevant genes and pathways. These targets should be evaluated in a larger cohort to determine their role in the molecular pathogenesis of MCC.

(c) 2015 S. Karger AG, Basel

\section{Introduction}

Merkel cell carcinoma (MCC) is a relatively rare neuroendocrine cancer with poor prognosis that is seen with increasing frequency in the USA [1]. It often presents in the sixth decade of life in patients of predominantly Caucasian ethnicity. Tumors arise in UV-exposed regions of the head and neck, upper thorax, and extremities [2]. The disease often presents as nonpainful nodules with local invasion in immunocompromised patients. Recently, a great deal of attention has focused on MCC due to the discovery of a viral pathogenesis for the disease [3].

MCC is a neuroendocrine neoplasm involving somatosensory cells present within the epidermis. Merkel cells, also known as Merkel-Ranvier cells or APUD cells (apparently unrelated endocrine cells), contain neuroen-

\section{KARGER 125}

(c) 2015 S. Karger AG, Base

0028-3835/15/1012-0112\$39.50/0

E-Mail karger@karger.com

www.karger.com/nen
Christian Graves

University of South Carolina School of Medicine

Bldg. 1 Room C27, 6439 Garners Ferry Rd.

Columbia, SC 20209 (USA)

E-Mail cgraves@uscmed.sc.edu 
docrine granules and detect coarse tactile stimuli. Their distribution occurs throughout the basal epidermis in both glabrous and haired skin including the nose, lips, and gingiva [4]. Merkel cells often juxtapose hair follicle bulges and Langerhans cells and are increased in mechanosensory and tactile-sensory regions. As such, these cells are innervated by $A \alpha$ nerve fibers of the peripheral nervous system [5]. This compartment is innervated at approximately 50 cells per nerve bouton and is principally served by mechano- $(\alpha \beta)$, proprio- ( $\gamma$ and $C)$, and nociceptive (A $\alpha$ and $\mathrm{C}$ ) fibers [6]. Merkel cells are putative mechanosensory cells of the epidermis; however, the direct mechanistic role they play in neoplasia remains poorly defined at the molecular level.

MCC is considered a nonmelanotic skin cancer and has only within the past several decades gained better definition. It was first described by Toker [7] as trabecular carcinoma of the skin, and its diagnosis was greatly facilitated by the advent of reliable cytokeratin 20 (CK20) immunohistochemical staining in the early 1990s $[8,9]$. Additionally, MCC lesions are positive for various granular neuroendocrine markers including chromogranin A (CgrA) and synaptophysin (Syn). Interestingly, in 2008 a DNA polyomavirus was identified and classified as the Merkel cell polyomavirus (MCPyV) that has since been detected in the majority of MCC cases $[3,10]$. Infection with $\mathrm{MCPyV}$ is believed to be associated with nearly $100 \%$ of MCC. Reactivation of latent MCPyV in immunocompromised individuals has been posited as an essential underlying pathogenic mechanism [11].

MCCs are clinically challenging to manage and often recur locally within a short time following initial resection. Management often includes broad excision followed by concurrent chemoradiation including 5 -fluorouridine (5-FU) and platinum-based regimen, and there are currently no FDA-approved targeted therapies.

The management and understanding of MCC have remained limited due to the absence of deep sequencing studies to determine potential mutations within these tumors $[12,13]$. To this end, we have implemented a massively parallel sequencing approach covering over 400 cancer-related genes in an attempt to further dissect some of the critical oncogene drivers in a cohort of MCC patients treated at our institution.

\section{Methods}

Patient Selection

All aspects of the study were approved by the William Jennings Bryan Dorn VA Medical Center Research Department and Insti- tutional Review Board. Retrospective chart reviews conducted from 1993 to 2013 revealed a total of 5 patients diagnosed and treated for neuroendocrine MCC. Patient demographics, clinical metrics, history, progression-free survival, and overall survival were analyzed.

\section{Diagnostic Pathology}

All cases were confirmed by a board-certified pathologist for histopathological small cell differentiation as well as CK20, Syn, and CgrA. Additionally, MCPyV large T antigen was analyzed in slides from the retrospective cases and reviewed.

\section{DNA Extraction and Massively Parallel Sequencing of 400}

Cancer-Related Genes

Genomic DNA was extracted from archival formalin-fixed paraffin-embedded tissue samples utilizing a formalin-fixed paraffinembedded DNA extraction kit as per the manufacturer's recommendations (Qiagen). Briefly, tissue was sectioned at $4 \mu \mathrm{m}$ with approximately 3 sections per block and deparaffinized in xylene. It was then washed with ethanol, and the sedimented samples were separated from residual solvent by evaporation. Samples were lysed in lysis buffer with $10 \%$ DNA proteinase $\mathrm{K}$ at $55^{\circ} \mathrm{C}$ for $60 \mathrm{~min}$ with an additional reversal of DNA cross-links at $90^{\circ} \mathrm{C}$ for $60 \mathrm{~min}$. Lysed tissue was then added to DNA columns and submitted to a series of washes with elution in water.

AmpliSeq (Life Technologies) DNA libraries were then prepared following the manufacturer's instructions. Briefly, for each specimen, $40 \mathrm{ng}$ of DNA was divided amongst four multiplex primer pools containing $10 \mathrm{ng}$ of template DNA. Approximately 4,000 target amplicons were amplified in each pool using the AmpliSeq Comprehensive Cancer Panel (CCP) primers and the standard AmpliSeq manufacturer's protocol. These amplicon pools were then combined and put through the remainder of the library preparation per the standard protocol. Libraries were diluted to $100 \mathrm{pM}$, combined in equal amounts, and used for template preparation of ion sphere particles (ISPs) per the manufacturer's instructions. Prior to sequencing, the percent of templated ISPs was verified to lie between 10 and $25 \%$, ensuring that the appropriate amount of library was added during the template preparation step. ISPs were then enriched and deposited on to a proton PI sequencing chip per the instructions given in the Ion PI Sequencing 200 Kit user guide. Six CCP libraries were sequenced simultaneously across two proton runs, yielding between 15.5M and 28M aligned reads per library. Alignment and variant identification was performed with Torrent Suite version 3.6.2, using high-stringency somatic detection settings.

\section{Statistical Analysis}

All statistical analyses were carried out using the Torrent Suite version 3.6.2 as described above.

\section{Results}

\section{Patient Demographics and Clinical Course}

Retrospective chart reviews conducted from 1993 to 2013 identified 5 patients treated at our institution and diagnosed with MCC. Patients fell within the typical di- 
Table 1. Patient demographics, pathology, treatment parameters, and relevant clinical comorbidities

\begin{tabular}{|c|c|c|c|c|c|c|c|c|c|c|}
\hline \multicolumn{3}{|c|}{ Demographics } & \multicolumn{2}{|c|}{ Pathology } & \multicolumn{2}{|l|}{ Therapy } & \multicolumn{4}{|c|}{ Comorbidities } \\
\hline $\begin{array}{l}\text { patient } \\
\text { No. }\end{array}$ & $\begin{array}{l}\text { sex/ } \\
\text { race }\end{array}$ & $\begin{array}{l}\text { age, } \\
\text { years }\end{array}$ & site & stage/grade & $\begin{array}{l}\text { resection sta- } \\
\text { tus }\end{array}$ & $\begin{array}{l}\text { treat- } \\
\text { ment }\end{array}$ & $\begin{array}{l}\text { alcohol/ } \\
\text { tobacco }\end{array}$ & $\begin{array}{l}\text { actinic } \\
\text { keratosis }\end{array}$ & $\begin{array}{l}\text { colon } \\
\text { cancer }\end{array}$ & $\begin{array}{l}\text { other } \\
\text { malignancy }\end{array}$ \\
\hline 1 & $\mathrm{M} / \mathrm{C}$ & 61 & Abd & & Bx, STR & - & Occ/Chron & $\mathrm{X}$ & $\mathrm{X}$ & $\mathrm{SCC}, \mathrm{CaP}$ \\
\hline 2 & $\mathrm{M} / \mathrm{C}$ & 82 & neck & T2N1M0/IIb & $\begin{array}{l}\mathrm{Bx}, \mathrm{ND} \\
(\times 2), \mathrm{GTR}\end{array}$ & $\mathrm{CT}$ & $\begin{array}{l}\text { NonU/ } \\
\text { NonU }\end{array}$ & $\mathrm{X}$ & $\mathrm{X}$ & SCC, BCC \\
\hline 3 & $\mathrm{M} / \mathrm{C}$ & 89 & inguinal & & $\mathrm{Bx}$ & $\mathrm{RT}$ & $\begin{array}{l}\text { NonU/ } \\
\text { NonU }\end{array}$ & & & $\begin{array}{l}\text { SCC, BCC, } \\
\text { Mel }\end{array}$ \\
\hline 4 & $\mathrm{M} / \mathrm{C}$ & 85 & head & T1N0M0/Ib & $\mathrm{Bx}, \mathrm{GTR}$ & RT & NonU/quit & $\mathrm{X}$ & $\mathrm{X}$ & SCC, BCC \\
\hline 5 & $\mathrm{M} / \mathrm{C}$ & 82 & neck & & STR, ND & - & $\begin{array}{l}\text { NonU/ } \\
\text { NonU }\end{array}$ & $\mathrm{X}$ & $\mathrm{X}^{\mathrm{a}}$ & SCC, BCC \\
\hline Average & & 79 & & & & & & $4(80 \%)$ & $4(80 \%)$ & \\
\hline
\end{tabular}

$\mathrm{M}=$ Male; $\mathrm{C}=$ Caucasian; $\mathrm{Abd}=$ abdominal; $\mathrm{Bx}=$ biopsy; $\mathrm{STR}=$ subtotal resection; $\mathrm{ND}=$ neck dissection; $\mathrm{GTR}=$ gross total resection; $\mathrm{CT}=$ chemotherapy; $\mathrm{RT}=$ radiotherapy Occ = occasional; Chron = chronic ; NonU = nonuser; $\mathrm{SCC}=$ squamous cell carcinoma; $\mathrm{CaP}=$ prostate carcinoma; $\mathrm{BCC}=$ basal cell carcinoma; $\mathrm{Mel}=$ melanoma.

a Colon polyps.

agnostic criteria with all being Caucasian males $>60$ years of age (mean: 80, range: 61-89) (table 1). Patients were referred to the clinic following the identification of characteristic MCC nodules. Interestingly, 80\% (4/5) patients presented with a past history of colon adenocarcinoma and actinic keratosis (table 1). One patient was incidentally diagnosed and treated with wide-band excision of the forehead. Three patients underwent direct biopsy with subsequent subtotal resection and $4 / 5$ patients underwent gross total salvage resection. Postoperative scans demonstrated marked disease reduction. Two patients completed follow-up radiation therapy while 1 patient underwent chemotherapy alone. Eighty percent of patients $(4 / 5)$ presented with a history of skin cancer and dermatological disorders at diagnosis (squamous cell carcinoma: $2 / 5,40 \%$; melanoma: $1 / 5,20 \%$; actinic keratosis $4 / 5,80 \%)$.

\section{Patient Pathology}

All diagnoses were confirmed by a board-certified pathologist with CgrA, Syn, and CK20, all common pathological markers of neuroendocrine MCC. All cases were positive for CgrA, Syn, and CK20 (fig. 1; table 2). Additionally, where available, tissue was stained for the surrogate marker MCPyV large T antigen which was present at the reported frequency of $75 \%$ of the cases with the most commonly used antibody (3/4 specimens) (fig. 1f).

\section{Massively Parallel Sequencing of Patient Samples}

Adequate tissue for DNA extraction was available from 4 archival patient specimens, and the blocks were selected for further analysis utilizing the Ion AmpliSeq CCP on Ion Proton instrumentation to assess somatic mutational spectra. The CCP is a multiplex PCR-based 409 gene-targeted panel with rapid high-throughput assessment of mutations based on the Wellcome Trust Sanger Institute's Cancer Gene Census. Within our data set, we called an average of 4,606 variants per patient $(\mathrm{n}=4 ; 4,472-4,762)$. One sample was found to maintain elevated variants at 12,226 called variants (online suppl. table I and fig. S2; for all online suppl. material, see www. karger.com/doi/10.1159/000370310). This is not unexpected as this specimen which was processed in higherconcentration formalin had been archived for a prolonged period of time of $>10$ years $[14,15]$. However, concomitant variants and deleterious mutations were detected within all genes that were interrogated within synonymous loci.

\section{Gene Mutational Spectrum Analysis}

Next-generation sequencing analysis revealed a spectrum of mutations which were present at high mutant allele frequencies (MAFs). The CCP contains exon-specific probes which specifically avoid homopolymers, and we corrected for the possibility of $\mathrm{G}>\mathrm{C}$ and $\mathrm{T}>\mathrm{A}$ transver- 

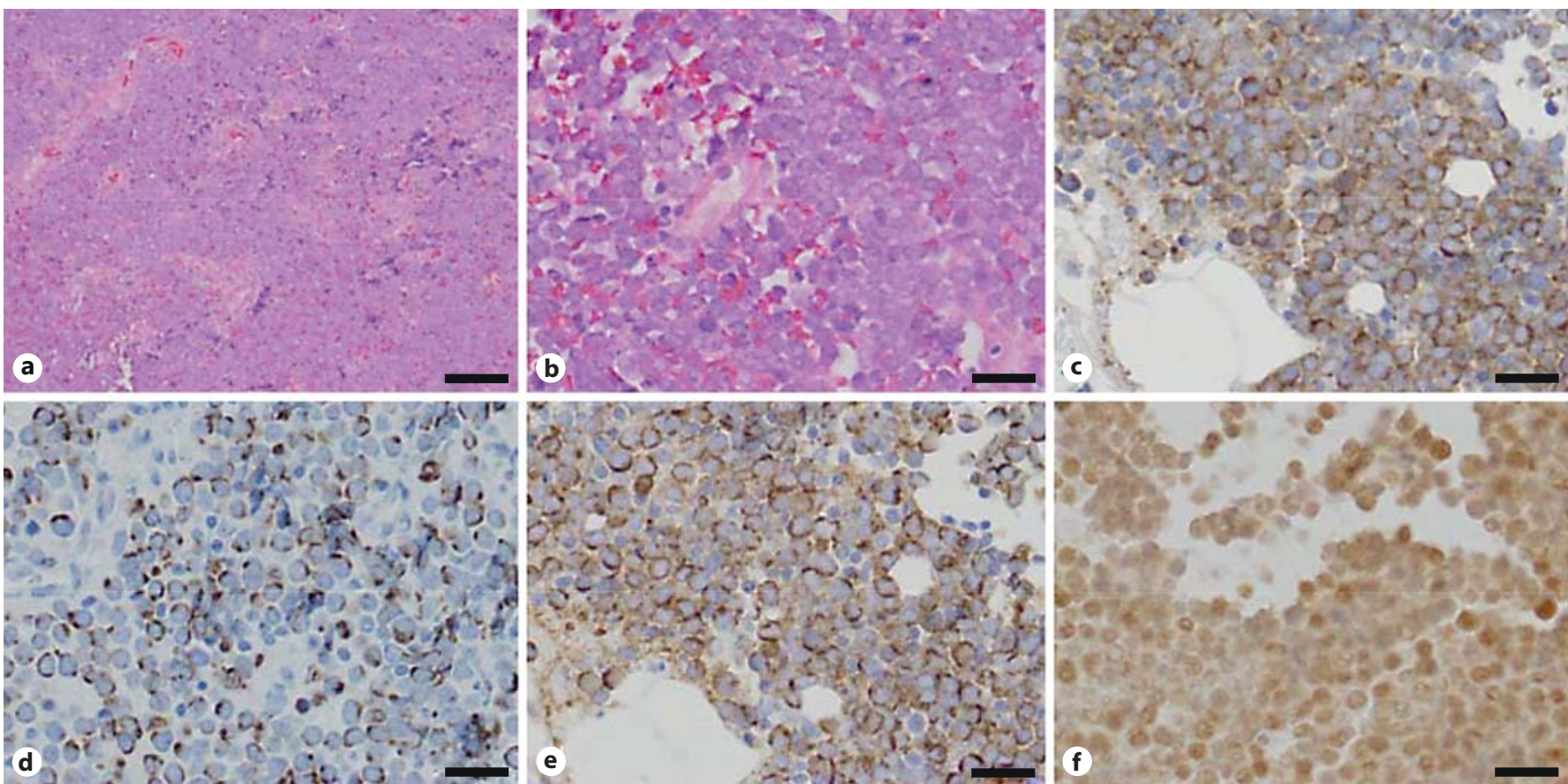

Fig. 1. Representative diagnostic anatomic pathology. a HE. $\times 10$. b HE. $\times 40$. c Syn. d CK20. e CgrA. f MCPyV large T antigen immunohistochemistry. $\times 40$ unless otherwise noted. Bars represent $200 \mu \mathrm{m}$.

Table 2. Immunohistochemical markers of neuroendocrine MCC

\begin{tabular}{lllll}
\hline Specimen & Syn & CgrA & CK20 & MCPyV LT \\
\hline I & + & + & + & + \\
II & + & + & + & + \\
IV & + & + & + & + \\
V & + & + & + & + \\
\hline
\end{tabular}

MCPyV LT = MCPyV large T antigen.

sions by focusing only on high MAFs. Due to the retrospective nature of the cohort, matched blood samples to determine somatic mutational status were unavailable. We therefore focused our analysis only on the most significant and penetrant mutations within our population.

\section{Nonsense Mutations}

Several nonsense mutations were detected in $75 \%$ of patients $(n=3 / 4)$ within the fourth exon of PDE4DIP (table 3). This gene encodes phosphodiesterase-4-interacting protein or myomegalin, a protein commonly associated with myelodysplastic disorders. Interestingly,

Neuroendocrine MCC and Associated Mutations
Table 3. Nonsense mutations in PDE4DIP (3/4; 75\%)

\begin{tabular}{llllll}
\hline Specimen & Coverage & Mutation & $\mathrm{AA}^{\Delta}$ & MAF & SNP db Ref \\
\hline I & - & - & - & - & - \\
II & 1,922 & C $>$ T & $560 \mathrm{~W}>*$ & 22.1 & \\
IV & 1,135 & G $>$ AG & $622 \mathrm{R}>*$ & 38.84 & rs 1778111 \\
V & 1,813 & C $>$ CT & $506 \mathrm{~W}>*$ & 30.34 & rs 1698683 \\
\hline
\end{tabular}

SNP $=$ Single nucleotide polymorphism. ${ }^{*}$ Indicates an SNP that encodes a stop codon at the given locus in the table.

phosphodiesterase-4D is a key interacting enzyme responsible for downstream inhibition of cyclic adenosine monophosphate (cAMP)-mediated activity within neural tissues [16]. Other mutations in critical DNA damage response genes protein kinase, DNA-activated, catalytic peptide [PRKDC $(50 \% ; 2 / 4)]$ were also detected but occurred at lower confidence MAFs (MAFs $=48.25$ and 2.65, respectively) (fig. 2; online suppl. table I).

\section{Insertion/Deletions and Missense Mutations}

We next focused our analysis on single nucleotide polymorphisms resulting in missense mutations with a 
Fig. 2. Mutations (MAF $>86 \%$ ) within the 4 sequenced samples. a Distribution of mutations within various genes on the CCC. b MLL3 gene with corresponding insertion in exon 14 within plant homeodomain (PHD) just upstream of the high-mobility group (HMG).

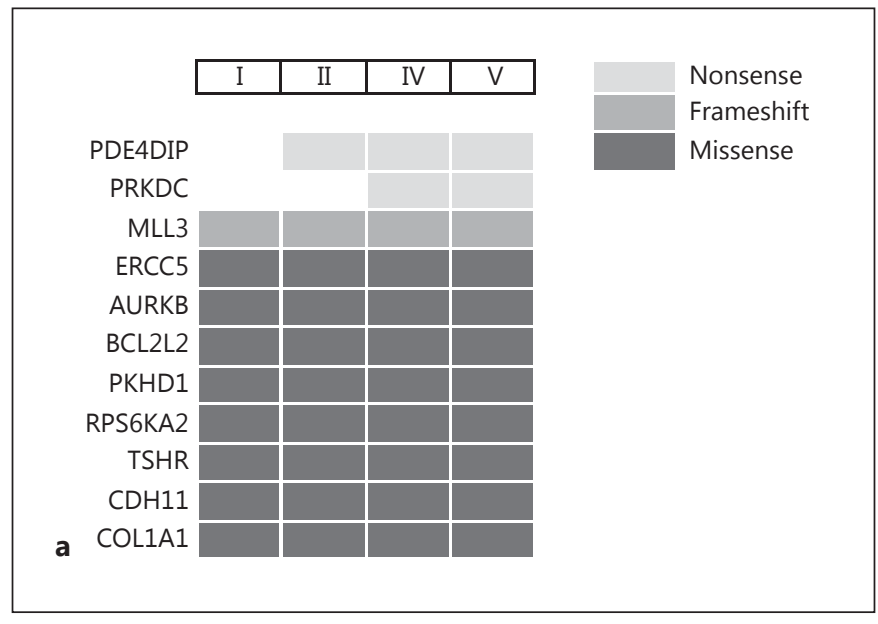

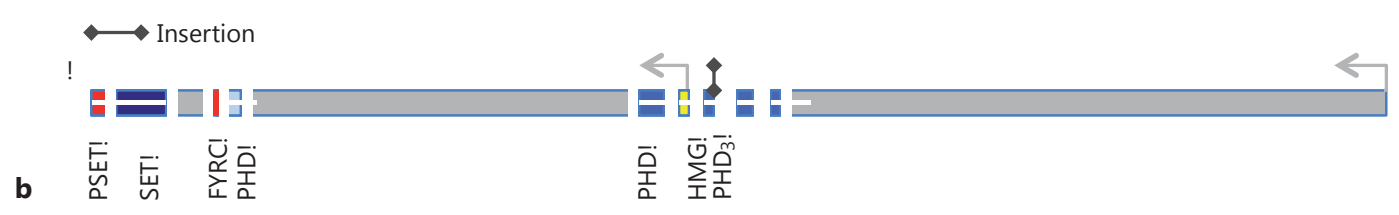

high MAF in our cohort ( $\mathrm{n}=45$ genes; MAF $>86 \%$ ). Importantly, many of these mutations are validated within functionally important coding domains based on the CCP. A 1-bp indel (insT) was present in exon 14 of MLL3 at high allelic frequency across all 4 samples, resulting in a frameshift mutation at tyrosine 816 (fig. 2b). Because this mutation was present in all 4 samples, we wanted to ensure that this was not a systematic error in the sequencing data. For example, Ion Torrent sequencing is susceptible to miscalling indels within homopolymer stretches due to the difficulty in resolving signal amplitudes for multiple bases of the same type [17]. We analyzed the mutation and demonstrated that the indel identified in all 4 samples does not reside within a homopolymer, thus reducing the possibility that this mutation is a systematic error (S2). Furthermore, the coverage across this mutation was over $1,000 \times$ in all samples, and there was no indication of strand or allelic bias. MLL3 encodes a nuclear-localized histone lysine-4 methyltransferase that is frequently deleted in myeloid leukemia and mutated in glioblastoma as well as pancreatic cancer [18].

Additional analysis revealed consensus frameshift mutations within a variety of genes associated with DNA damage repair and apoptosis. A missense mutation in all of the samples at position 1,053 (glycine to arginine) in the ERCC5 gene associated with xeroderma pigmentosum $(\mathrm{MAF}>99 \% ; 3 / 4)$ and an additional missense within the same region $1080 \mathrm{G}>\mathrm{R}$ (MAF 99.13; 1/4) was observed. Intriguingly, this missense mutation is present upstream of the nuclear localization sequence and represents a highly conserved residue in the enzyme. ERCC5, also known as XR-5, is a critical regulator in the nucleotide excision repair (NER) pathway, whereby it removes nucleotide adducts following chronic UV irradiation. It has been noted that MCC is most prevalent in pale-skinned UV-exposed regions of the body wherein NER is critical to maintaining genomic integrity.

We also observed a missense mutation at $298^{\mathrm{M}>\mathrm{T}}$ (MAF $>99 \%$; 4/4) in the aurora kinase $\beta$ (AURKB) gene. AURKB is a cofactor critical to maintaining mitotic integrity that is activated in response to UV irradiation at the centromere, and overexpression has been demonstrated to preclude chromosomal aneuploidy in colon cancer $[19,20]$. Furthermore, AURKB interacts with survivin at the centromere which has recently been described as clinical target in MCC [21]. An identical mutation in the large intestine has been documented in the AURKB gene and $3 / 4$ of our patients intriguingly had been treated previously for colon carcinoma (COSMIC) [22]. 
Misssense mutations were observed in several other DNA repair pathways including the ataxia telangiectasia rad6-related one (ATR; 4/4) within the ATRIP-binding domain and the associated ATRX (3/4). This is an important regulator of cell cycle progression following DNA damage, and ATRIP has been demonstrated to modulate the activity of ATR in initiating DNA damage repair (fig. 3).

Single-nucleotide polymorphism of the thyroidstimulating hormone receptor (TSHR) was synonymously identified at position $727^{\mathrm{E}>\mathrm{D}}(\mathrm{MAF}>98 \%)$. Mutations in BCL2L2, an antiapoptotic factor related to the BCL-2 family, demonstrated a glutamine to arginine mutation at position 133 (MAF $>97 \%$; 4/4). Synonymous mutations in the COL1A1 $\left(1075^{\mathrm{T}>\mathrm{A}} \mathrm{MAF}>99 \%\right.$; 4/4) gene were also detected with high frequency [23]. Taken together, these germline mutations hold potential as novel targets that have not been previously described in MCC.

\section{Discussion}

Several well-powered studies evaluating the mutational spectrum in MCC have recently been conducted; however, these studies have not yet deeply sequenced tumors for a predicted mutational spectrum $[12,13,24]$. Within our focused cohort, we implemented a targeted 409-gene screen in 4 patients and demonstrated potential targets with relevance to Merkel cell disease. Importantly, we observed frequent nonsense mutations in PDE4DIP - better known as myomegalin - within 3/4 of the patients included in this study. Myomegalin is a predicted oncogene and gain-of-function mutations have been implicated in myeloproliferative disorders. Evaluation of CBC counts did not implicate aberrant mutations at the time of diagnosis suggesting a somatic mutation. All nonsense mutations occurred within the fourth coiled domain directly upstream of a breakpoint site within known PDE4DIPPDGFRB fusion [25].

Missense mutations within key DNA damage and apoptosis genes were also detected. H3K4 histone methyltransferase MLL3 demonstrated an insertion in all the patients included in our study. This mutation adds a tyrosine residue upstream within the highly conserved plant homology domains which flank the transactivation domain and are important in CREB-mediated gene expression [26]. MLL3 mutations have been previously demonstrated in other aggressive neuroendocrine tumors including pancreatic neoplasms as well as medul-

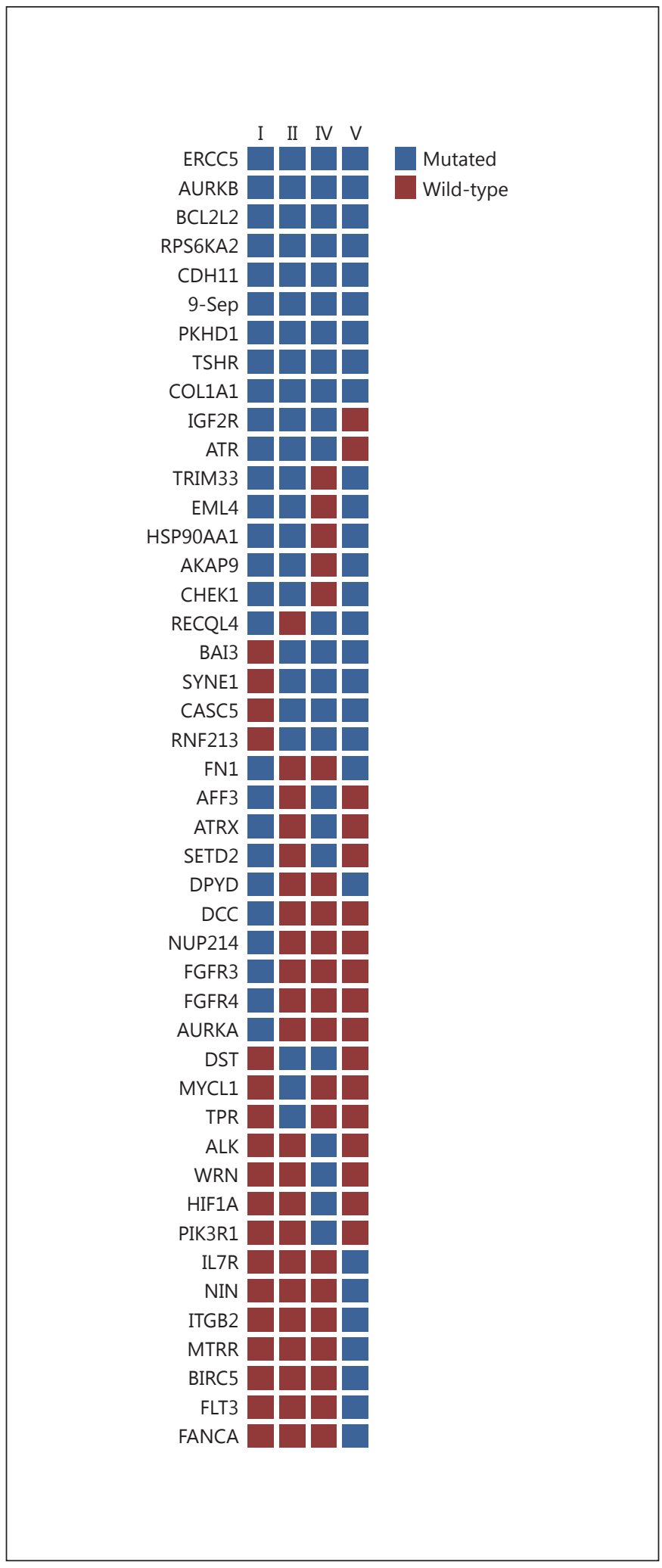

Fig. 3. Selected missense mutations within the cohort of patients. Samples with missense mutations are noted in blue while nonmutated samples appear in red. 
loblastomas [27]. Furthermore, MLL1 - a close analog of MLL3 and component of the methyltransferase complex - is essential for postnatal neurogenesis indicating a potential overlap of $\mathrm{H} 3 \mathrm{~K} 4$ methylation and overactivation in the neuroendocrine compartment [28]. Our study demonstrates a potentially novel missense mutation in MCC within the ERCC5 gene proximal to the nuclear localization sequence which was present in our cohort predominantly as a glycine to arginine substitution. In vitro work has recently linked ERCC5 signaling with ATR-ATRIP signaling in DNA damage responses to UV. In addition, the UV-induced damage repair pathway is known to activate AURKB which interacts with downstream BCL2L2 and antiapoptotic pathways. Therefore, it will be of great interest to determine whether loss of function at these loci is incurred with these mutations [29]. In our cohort, a glutamic to aspartic acid mutation at position 727 of the TSHR gene was present in high allelic frequency. Interestingly, recent studies have indicated this single nucleotide polymorphism, denoted as rs1991517, to be associated with an enhanced risk of thyroid cancer, DNA damage and RET oncogene polymorphism in populations exposed to ionizing radiation [30].

BCL2L2 is an antiapoptotic gene of great current clinical interest. It is upregulated downstream of $N F \kappa \beta$ mediated prosurvival signaling and is involved in nervous tissue responses to BDNF and NGF [31]. Interactions between UV-induced DNA damage response and apoptotic pathways (ERCC5, AURKB, and BCL2L2) and receptorresponsive elements (PDE4DIP and TSHR) could provide potential preclinical targets for validation in MCC.

Randomized clinical trials incorporating targeted therapies such as pazopanib or imatinib are underway but are hindered by the rarity of MCC; they are, however, necessary to improve outcomes [32]. Pazopanib is a panreceptor tyrosine kinase (RTK) inhibitor with activity in a variety of kinases including PDGFRA and FGFR3, which is under early-phase clinical testing in MCC [33, 34]. Various immunotherapy trials are underway, evaluating the utilization of IL-12 gene therapy and large T antigen priming in MCC. Additionally, the potential PDGFRA-PDE4DIP fusion previously reported could also represent a potential clinical target. However, Swick et al. [35] considered PDGFRA-KIT expression in a focused cohort of 23 tumors demonstrating a 95 and 65\% expression of these markers, respectively, but found no activating mutations. It will be of great interest to determine whether the DNA damage and prosurvival pathways play a role in a larger cohort of this aggressive neuroendocrine cancer.

\section{Conclusions}

Within our small cohort of MCC cases, various genetic mutations were detected with potential relevance to MCC pathogenesis. UV exposure is a risk factor for MCC, and we describe a mutation in ERCC5, a gene which encodes a protein important in UV-induced NER and that is implicated in xeroderma pigmentosum $[36,37]$. All of the patients sequenced in this cohort demonstrated other UV-associated dermatological conditions including actinic keratosis and skin cancers $[38,39]$. Additionally, we found mutations in PDE4DIP, a gene which encodes a regulatory binding protein important in neural tissue-associated calcium-mediated cAMP signaling. We also detected a high frequency of mutations within genes important in maintaining genomic stability including MLL3, AURKB, and BCL2L2. MCC is an increasingly common diagnosis, yet our center observed 5 total cases with variable tissue fixation and increased nonsynonymous variants. Therefore, further validation of these genes in larger associational cohorts and their significance as potential therapeutic targets and/or clinical prognostic indicators will lead to better direct clinical decisions and understanding of the underlying molecular drivers of Friedrich Sigmund Merkel carcinoma [40].

\section{Acknowledgments}

This work was supported by VA Institutional Research Funds awarded to J.W. C.A.G. and L.P. were supported by the NIMHD grant No. 1P20MD001770.

\section{Disclosure Statement}

The authors declare no conflicts of interest in the preparation of this work.

References

1 Schrama D, Ugurel S, Becker JC: Merkel cell carcinoma: recent insights and new treatment options. Curr Opin Oncol 2012;24:141-149.

-2 Lemos B, Nghiem P: Merkel cell carcinoma: more deaths but still no pathway to blame. J Invest Dermatol 2007;127:2100-2103.

- 3 Feng H, Shuda M, Chang Y, Moore PS: Clonal integration of a polyomavirus in human Merkel cell carcinoma. Science 2008;319: 1096-1100.

4 Winkelmann RK, Breathnach AS: The Merkel cell. J Invest Dermatol 1973;60:2-15.

5 Boulais N, Misery L: Merkel cells. J Am Acad Dermatol 2007;57:147-165. 
6 Lumpkin EA, Bautista DM: Feeling the pressure in mammalian somatosensation. Curr Opin Neurobiol 2005;15:382-388.

7 Toker C: Trabecular carcinoma of the skin. Arch Dermatol 1972;105:107-110.

8 Moll R, Lowe A, Laufer J, Fanke WW: Cytokerain 20 in human carcinomas. A new histodiagnostic marker detected by monoclonal antibodies. Am J Pathol 1992;140:427-447.

-9 Erovic I, Erovic BM: Merkel cell carcinoma: the past, the present, and the future. J Skin Cancer 2013;2013:929364.

10 Erovic BM, Al Habeeb A, Harris L, Goldstein DP, Ghazarian D, Irish JC: Significant overexpression of the Merkel cell polyomavirus $(\mathrm{MCPyV})$ large $\mathrm{T}$ antigen in Merkel cell carcinoma. Head Neck 2013;35:184-189.

11 Wiedinger K, Bitsaktsis C, Chang S: Reactivation of human polyomaviruses in immunocompromised states. J Neurovirol 2014;20: $1-8$.

$>12$ Rodig SJ, Cheng J, Wardzala J, DoRosario A, Scanlon JJ, Laga AC, Martinez-Fernandez A, Barletta JA, Bellizzi AM, Sadasivam S, Holloway DT, Cooper DJ, Kupper TS, Wang LC, DeCaprio JA: Improved detection suggests all Merkel cell carcinomas harbor Merkel polyomavirus. J Clin Invest 2012;122:4645-4653.

$\checkmark 13$ Nardi V, Song Y, Santamaria-Barria JA, Cosper AK, Lam Q, Faber AC, Boland GM, Yeap BY, Bergethon K, Scialabba VL, Tsao H, Settleman J, Ryan DP, Borger DR, Bhan AK, Hoang MP, lafrate AJ, Cusack JC, Engleman JA, Dias-Santagata D: Activation of PI3K signaling in Merkel cell carcinoma. Clin Cancer Res 2012;18:1227-1236.

-14 Srinivasan M, Sedmak D, Jewell S: Effect of fixatives and tissue processing on the content and integrity of nucleic acids. Am J Pathol 2002;161:1961-1971.

15 Williams C, Pontén F, Moberg C, Söderkvist P, Uhlén M, Pontén J, Sitbon G, Lundeberg J: A high frequency of sequence alterations is due to formalin fixation of archival specimens. Am J Pathol 1999;155:1467-1471.

16 de Vente J, Markerink-van Ittersum M, Vles JS: ANP-mediated cGMP signaling and phosphodiesterase inhibition in the rat cervical spinal cord. J Chem Neuroanat 2006;31:236274.

17 Margulies M, Egholm M, Altman WE, et al: Genome sequencing in microfabricated highdensity picolitre reactors. Nature 2005;437: 376-380.

18 Balakrishnan A, Bleeker FE, Lambda S, Rodolfo M, Daniotti M, Scarpa A, van Tillborg AA, Leenstra S, Zanon C, Bardelli A: Novel somatic and germline mutations in cancer candidate genes in glioblastoma, melanoma, and pancreatic carcinoma. Cancer Res 2007; 67:3545-3550.
19 Burum-Auensen E, DeAngelis PM, Schjolberg AR, Roislien J, Mjaland O, Clausen OP: Reduced level of the spindle checkpoint protein BUB1B is associated with aneuploidy in colorectal cancers. Cell Prolif 2008;41:645659.

20 Schjolberg AR, Clauen OPF, Burum-Auensen E, De Angelis PM: Aneuploidy is associated with TP53 expression but not with BRCA1 or TERT expression in sporadic colorectal cancer. Anticancer Res 2009;29:4381-4387.

-21 Arora R, Shuda M, Guastafierro A, Feng H, Toptan T, Tolstov Y, Normolle D, Vollmer LL, Vogt A, Dömling A, Brodsky JL, Chang Y, Moore PS: Survivin is a therapeutic target in Merkel cell carcinoma. Sci Transl Med 2012; 4:133ra56.

22 COSMIC: http://cancer.sanger.ac.uk/gb2// gbrowse $/$ cosmic $/$ ? name $=17 \% 3$ A $8108325 . .81$ 08335; label=Chromosome\%3Aoverview\%2B Genes\%3Aregion\%2BCosmicGenes\%2BMut ations\%2BStructuralVariants\%2BCNA_ hd\%2BCNA_loh\%2BCNA_amp\%2BCNA_ change (accessed October 2, 2013).

23 Giampieri R, Scartozzi M, Loretelli C, Piva F, Mandolesi A, Lezoche G, Prete MD, Bittoni A, Faloppi L, Bianconi M, Cecchini L, Guerrieri M, Bearzi I, Cascinu S: Cancer stem cell gene profile as predictor of relapse in high risk stage ii and stage iii, radically resected colon cancer patients. PLoS One 2013;8:e72843.

24 Kartha RV, Sundram UN: Silent mutations in KIT and PDGFRA and co-expression of receptors with SCF and PDGFRA in Merkel cell carcinoma: implications for tyrosine kinasebased tumorigenesis. Mod Pathol 2008;21: 96-104.

25 Wilkinson K, Velloso ER, Lopes LF, Lee C, Aster JC, Shipp MA, Aguiar RC: Cloning of the $\mathrm{t}(1 ; 5)(\mathrm{q} 23 ; \mathrm{q} 33)$ in a myeloproliferative disorder associated with eosinophilia: involvement of PDGFRB and response to imatinib. Blood 2003;102:4187-4190.

26 Ernst P, Wang J, Huang M, Goodman RH, Korsmeyer SJ: MLL and CREB bind cooperatively to the nuclear coactivator CREB-binding protein. Mol Cell Biol 2001;21:2249-2258.

27 Parsons DW, Li M, Zhang X, Jones S, Leary RJ, Lin JC, Boca SM, Carter H, Samayoa J, Bettegowda C, Gallia GL, Jallo GI, Binder ZA, Nikolsky Y, Hartigan J, Smith DR, Gerhard DS, Fults DW, VandenBerg S, Berger MS, Marie SK, Shinjo SM, Clara C, Phillips PC, Minturn JE, Biegel JA, Judkins AR, Resnick AC, Storm PB, Curran T, He Y, Rasheed BA, Friedman HS, Keir ST, McLendon R, Northcott PA, Taylor MD, Burger PC, Riggins GJ, Karchin R, Parmigiani G, Bigner DD, Yan H, Papadopoulos N, Vogelstein B, Kinzler KW, Velculescu VE: The genetic landscape of the childhood cancer medulloblastoma. Science 2011;331:435-439.
28 Lim DA, Huang YC, Swigut T, Mirick AL, Garcia-Verdugo JM, Wysocka J, Ernst P, Alvarez-Buylla A: Chromatin remodeling factor Mll1 is essential for neurogenesis from postnatal neural stem cells. Nature 2009;458:529533.

29 Lindsey-Boltz LA, Kemp MG, Reardon JT, Derocco V, Iyer RR, Modrich P, Sancar A: Coupling of human DNA excision repair and ATR-mediated DNA damage checkpoint in a defined in vitro system. J Biol Chem 2014;289: 5074-5082.

30 Sigurdson AJ, Land CE, Bhatti P, Pineda M, Brenner A, Carr Z, Gusev BI, Zhumadilov Z, Simon SL, Bouville A, Rutter JL, Ron E, Struewing JP: Thyroid nodules, polymorphic variants in DNA repair and RET-related genes, and interaction with ionizing radiation exposure from nuclear tests in Kazakhstan. Radiat Res 2009;171:77-88.

31 Middleton G, Wyatt S, Ninkina N, Davis AM: Reciprocal developmental changes in the roles of $\mathrm{Bcl}-\mathrm{W}$ and $\mathrm{Bcl}-\mathrm{x}(\mathrm{L})$ in regulating sensory neuron survival. Development 2001;128: 447-457.

32 Desch L, Kunstfeld R: Merkel cell carcinoma: chemotherapy and emerging new therapeutic options. J Skin Cancer 2013;2013:327150.

33 Cancer Research UK; Pazopanib Trial: http:// www.cancerresearchuk.org/about-cancer/ trials/a-trial-of-pazopanib-for-merkel-cellcarcinoma-ukmcc-01.

34 Davids D, Charlton A, Ng S-S, Chong M-L, Laubscher K, Dar M, Hodge J, Soong R, Goh $\mathrm{BC}$ : Response to a novel multitargeted tyrosine kinase inhibitor pazopanib in metastatic Merkel cell carcinoma. J Clin Oncol 2009; 27:e97-e100.

35 Swick BL, Srikantha R, Messingham KN: Specific analysis of KIT and PDGFR-alpha expression and mutational status in Merkel cell carcinoma. J Cutan Pathol 2013;40:623-630.

-36 Senchenkov A, Barnes SA, Moran SL: Predictors of survival and recurrence in the surgical treatment of Merkel cell carcinoma of the extremities. J Surg Oncol 2007;95:229-234.

37 Grotz TE, Tarantola TI, Otley CC, Weaver AL, McGree ME, Jakub JW: Natural history of Merkel cell carcinoma following locoregional recurrence. Ann Surg Oncol 2012;19:25562562.

38 Ferrara G, Goos SD, Stefanato CM: Merkel cell carcinoma in situ associated with actinic keratosis: fortuitous or serendipitous? J Cutan Pathol 2010;37:1112-1113.

39 Werner RN, Sammain A, Erdmann R, Hartmann V, Stockfleth E, Nast A: The natural history of actinic keratosis: a systematic review. Br J Dermatol 2013;169:502-518.

40 Merkel F: Tastzellen und Tastkörperchen bei den Hausthieren und beim Menschen. Arch Mikrosk Anat 1875;11:636-652. 